\title{
Analysis of Marketable and Marketed Surplus of Paddy in Tirunelveli District of Tamil Nadu, India
}

\author{
K. S. Mohana Priya*, R. Senthilkumar, C. Muralidharan and R. Pangayar Selvi \\ Department of Social Sciences, Tamil Nadu Agricultural University, Agricultural College and \\ Research Institute, Killikulam, India \\ *Corresponding author
}

\section{A B S T R A C T}

\begin{tabular}{|l|}
\hline Ke y w o r d s \\
Marketable and \\
marketed surplus, \\
Paddy, Farm \\
requirement
\end{tabular}

\section{Introduction}

India is one of the largest producers of rice accounts for 20 per cent of world production. Paddy cultivation is one of the most important agricultural operations in the country. Development of the country is based on increasing agricultural productivity as it is the base for industrialization and expansion of marketed surplus to enhance the process of development. The marketed surplus is therefore as important as total production in influencing market prices. In an economy, increasing marketable surplus can contribute to capital formation. With the use of modern inputs, HYV seeds, irrigation, improved technologies and other facilities, production can be increased leading to higher marketed surplus and economic prosperity of the farmers. The marketed surplus ratio of rice has increased from 60 per cent in mid-nineties to about 80 per cent (Government of India, 2015). It is the need of the hour to find the determinants of marketed surplus to design appropriate production, procurement, storage, distribution and pricing policies.

The objectives of this study includes to estimate marketable and marketed surplus of paddy and utilization pattern and to analyse the factors influencing marketable and marketed surplus. 


\section{Materials and Methods}

\section{Data and sampling}

The major crop cultivated in Tirunelveli is paddy. Out of 14 blocks in Tirunelveli, Ambasamudram block was purposively selected due to highest area under paddy. Paddy farmers were stratified into three groups viz., small (up to 2 hectares), medium ( 2 to 5 hectares) and large (above 5 hectares) based on area under paddy farming. Totally 40 farmers (12 small, 14 medium and 14 large) were selected randomly from the block. Required primary data were collected through personal interview method with the help of pre-tested interview schedule for the year 2019-20. Major tools used for the study were multiple regression technique and tabular analysis.

\section{Concepts used}

Farm requirement: Includes the quantity retained for family consumption, seed and feed, wages in kind and other losses.

Marketable surplus: Quantity retained after meeting out all the requirements of farmer.

Marketed surplus: The actual quantity sold by the farmers in the market.

\section{Factors influencing marketable surplus}

Marketable surplus in different farm groups were influenced by various factors. Some of the factors identified as most important for the variation in marketable surplus on different farm groups was area under paddy, average productivity, family size and wages in kind. To identify the effect of these factors on marketable surplus, multiple regression technique was employed (Pramod Kumar, 1999). The functional model used to analyze the factors influencing marketable surplus is

$$
\mathrm{Y}=\mathrm{b}_{0}+\mathrm{b}_{1} \mathrm{X}_{1}+\mathrm{b}_{2} \mathrm{X}_{2}+\mathrm{b}_{3} \mathrm{X}_{3}+\mathrm{b}_{4} \mathrm{X}_{4}
$$

Where, $\mathrm{Y}=$ Marketable surplus

$\mathrm{a}=$ Constant

$\mathrm{X}_{1}=$ Area under paddy

$\mathrm{X}_{2}=$ Average productivity

$\mathrm{X}_{3}=$ Family size

$\mathrm{X}_{4}=$ Wages in kind

$b_{i}{ }^{\prime} s=$ Regression coefficients

\section{Factors influencing Marketable surplus}

Similarly, marketed surplus was also influenced by various factors like family size, area under paddy, total production, family retention, financial obligations $(0$ for borrowers and 1 for non borrowers) and current prices (Amruta Borate, 2011). The functional model employed to determine the effect of these factors on the marketed surplus was

$\mathrm{Y}=\mathrm{b}_{0}+\mathrm{b}_{1} \mathrm{X}_{1}+\mathrm{b}_{2} \mathrm{X}_{2}+\mathrm{b}_{3} \mathrm{X}_{3}+\mathrm{b}_{4} \mathrm{X}_{4}+\mathrm{b}_{5} \mathrm{X}_{5}+\mathrm{b}_{6} \mathrm{X}_{6}$

Where, $\mathrm{Y}=$ Marketed surplus

$\mathrm{a}=$ Constant

$\mathrm{X}_{1}=$ Family size

$\mathrm{X}_{2}=$ Area under paddy

$\mathrm{X}_{3}=$ Total production

$\mathrm{X}_{4}=$ Family consumption

$\mathrm{X}_{5}=$ Financial obligation

$\mathrm{X}_{6}=$ Current prices

$b_{i}{ }^{\prime} s=$ Regression coefficients

\section{Results and Discussion}

\section{Estimation of marketable and marketed surplus}

Paddy being a staple food crop holding behavior is more so that marketable surplus is lower than that of other crops. Total production, pattern of utilization, marketed and marketable surplus of the sample farms are presented in Table 1. Average production of paddy was 4.322 tonnes of which 21.12 per 
cent (0.913 tonnes) was farm requirement. Total production was highest in large farms followed by medium and small farms. The quantity retained for family consumption was 16.28 per cent, for seed purpose 4.20 per cent, as wages 0.20 per cent and 0.45 per cent includes losses on farm. Results showed that quantity retained for seed purpose increased as farm size increases. This might be because of the fact that small farmers face distressed sale to meet out their financial obligations.

Overall marketed surplus was 77.17 per cent of total production highest in small farms (83.65 per cent) followed by medium (75.40 per cent) and large farms (74.03 percent). It can be seen from the table that marketable surplus is higher than marketed surplus in case of large farms while marketable surplus is lower than marketed surplus in case of small farms. It might be due to the fact that retention capacity increases with increase in farm size.

\section{Factors influencing marketable surplus}

By using multiple regression technique, the factors influencing marketable surplus was analyzed and the results were presented in Table 2. It can be observed that the $\mathrm{R}^{2}$ values of the regression equations were more than 0.83 indicates that more than 83 per cent variations in marketable surplus was explained by the variables taken. Area under paddy $\left(\mathrm{X}_{1}\right)$ and average productivity $\left(\mathrm{X}_{2}\right)$ was positive and significant in all farm groups implies that marketable surplus increases with increase in these variables. Overall, family size $\left(\mathrm{X}_{3}\right)$ and wages in kind $\left(\mathrm{X}_{4}\right)$ was negative and significant indicating that marketable surplus decreases with an increase in family size and quantity retained for wages.

Table.1 Pattern of utilization of paddy

\begin{tabular}{|l|l|c|c|c|c|}
\hline S.No & Particulars & $\begin{array}{c}\text { Small } \\
(\mathbf{n = 1 2})\end{array}$ & $\begin{array}{c}\text { Medium } \\
(\mathbf{n = 1 4})\end{array}$ & $\begin{array}{c}\text { Large } \\
(\mathbf{n = 1 4})\end{array}$ & $\begin{array}{c}\text { Overall } \\
(\mathbf{n = 4 0})\end{array}$ \\
\hline $\mathbf{1}$ & Total production & $\begin{array}{c}3.985 \\
(100.00)\end{array}$ & $\begin{array}{c}4.329 \\
(100.00)\end{array}$ & $\begin{array}{c}4.602 \\
(100.00)\end{array}$ & $\begin{array}{c}4.322 \\
(100.00)\end{array}$ \\
\hline $\mathbf{2 .}$ & Farm requirement & & & & \\
\hline & i) Family consumption & 0.627 & 0.708 & 0.765 & 0.703 \\
& & $(15.74)$ & $(16.35)$ & $(16.61)$ & $(16.28)$ \\
\hline & ii) Seed & 0.135 & 0.194 & 0.209 & 0.181 \\
& & $(3.39)$ & $(4.47)$ & $(4.55)$ & $(4.20)$ \\
\hline & iii) Wages paid in kind & 0.007 & 0.009 & 0.010 & 0.009 \\
& & $(0.17)$ & $(0.20)$ & $(0.22)$ & $(0.20)$ \\
\hline & iv) Losses & 0.032 & 0.014 & 0.014 & 0.019 \\
& & $(0.80)$ & $(0.32)$ & $(0.31)$ & $(0.45)$ \\
\hline & Total & 0.801 & 0.924 & 0.998 & 0.913 \\
\hline 3. & Marketable surplus & $(20.09)$ & $(21.34)$ & $(21.69)$ & $(21.12)$ \\
\hline & & 3.184 & 3.405 & 3.604 & 3.409 \\
\hline $\mathbf{4 .}$ & Marketed surplus & $(79.91)$ & $(78.66)$ & $(78.31)$ & $(78.88)$ \\
\hline
\end{tabular}

*Figures in parenthesis indicate percentage 
Table.2 Factors influencing Marketable surplus

\begin{tabular}{|c|c|c|c|c|}
\hline \multirow{2}{*}{ Particulars } & \multicolumn{4}{|c|}{ Farm size groups } \\
\cline { 2 - 5 } & Small & Medium & Large & Overall \\
\hline Constant & 0.5389 & 0.1137 & -0.7300 & -0.0239 \\
\hline $\mathbf{X}_{\mathbf{1}}$ (Area under paddy) & $0.0041^{* *}$ & $0.0562^{*}$ & $0.0184^{*}$ & $0.0007^{* *}$ \\
\hline $\begin{array}{c}\mathbf{X}_{\mathbf{2}} \text { (Average } \\
\text { productivity) }\end{array}$ & $0.6777^{*}$ & $0.6599 \mathrm{NS}$ & $1.0036^{*}$ & $0.8398^{*}$ \\
\hline $\mathbf{X}_{\mathbf{3}}$ (Family size) & $-0.0347^{*}$ & $-0.0556^{* *}$ & $-0.0480^{* *}$ & $-0.0089^{*}$ \\
\hline $\mathbf{X}_{\mathbf{4}}$ (Wages in kind) & $-5.1829^{*}$ & $-0.0325^{*}$ & $3.9670 \mathrm{NS}$ & $-2.5605^{*}$ \\
\hline $\mathbf{R}^{\mathbf{2}}$ & 0.88 & 0.89 & 0.91 & 0.83 \\
\hline
\end{tabular}

Note: ** indicates significance at $1 \%,{ }^{*}$ Indicates significance at $5 \%,{ }^{\mathrm{NS}}$ - Not significant

Table.3 Factors influencing Marketed surplus

\begin{tabular}{|c|c|c|c|c|}
\hline \multirow[t]{2}{*}{ Particulars } & \multicolumn{4}{|c|}{ Farm size groups } \\
\hline & Small & Medium & Large & Overall \\
\hline Constant & 7.4172 & -0.0861 & 3.3135 & $2.0371 *$ \\
\hline $\mathbf{X}_{1}$ (Family size) & $-0.0736^{*}$ & $-0.0706^{*}$ & $-0.1020 * *$ & $-0.0642 * *$ \\
\hline$X_{2}$ (Area under paddy) & $0.7952 *$ & $0.0394 * *$ & $0.0144^{*}$ & $0.0339 *$ \\
\hline $\mathbf{X}_{3}$ (Total production) & $0.5644 * *$ & $0.9117^{*}$ & $0.7841^{*}$ & $0.8146 * *$ \\
\hline $\mathrm{X}_{4}$ (Family consumption) & $-1.3886^{*}$ & $-1.6530 * *$ & $-0.4788 \mathrm{NS}$ & $-0.8220 *$ \\
\hline $\mathrm{X}_{5}$ (Financial obligation) & $0.0045^{*}$ & $0.0002 *$ & $0.0017 * *$ & $0.0008 *$ \\
\hline $\mathbf{X}_{6}$ (Current prices) & $0.1324 * *$ & $0.0968 \mathrm{NS}$ & $0.0841 *$ & $0.0886 *$ \\
\hline $\mathbf{R}^{2}$ & 0.71 & 0.78 & 0.73 & 0.81 \\
\hline
\end{tabular}

Note: $* *$ indicates significance at $1 \%,{ }^{*}$ Indicates significance at $5 \%,{ }^{\mathrm{NS}}$ - Not significant

\section{Factors influencing marketed surplus}

Various factors influencing marketed surplus were analyzed and the results were presented in Table 3. The $\mathrm{R}^{2}$ values of the regression equations were more than 0.71 indicates that more than 71 per cent variations in marketable surplus was explained by the variables taken. From the table, it can be observed that family size $\left(\mathrm{X}_{1}\right)$ and family consumption $\left(\mathrm{X}_{4}\right)$ was negative while area under paddy $\left(\mathrm{X}_{2}\right)$, total production $\left(\mathrm{X}_{3}\right)$, financial obligation $\left(\mathrm{X}_{5}\right)$ and current prices $\left(\mathrm{X}_{6}\right)$ showed positive and significant relationship with marketed surplus.

In conclusion as a whole, average marketable surplus of paddy was 78.88 per cent, marketed surplus was 77.17 per cent and 21.12 per cent for farm requirement. It is evident from the results that percentage of marketable surplus increases with increase in farm size. Area and average productivity were significantly and positively related with marketable surplus. Average productivity can be increased with implementing new technologies in production so that marketable surplus can be increased. Area, production, financial obligation and current prices showed positive relationship with marketed surplus while family size and family consumption showed inverse relationship. On small farms, marketed surplus was greater than marketable surplus implying forced selling to meet out their current expenditure needs. Marketing loan and storage provisions can be provided 
in an easily accessible way for small farmers to avoid distress sale of their produce. To enhance marketable and marketed surplus, production and average productivity can be increased for the economic prosperity of farmers.

\section{References}

Borate, A., Zala Y. C., Darji, V.B., and Yadav, K.S. 2011. Analysis of marketable and marketed surplus of red gram in Vadodara district of Gujarat. Legume Research and International Journal. 34(4):267-272.

Dwivedi and Jha. 2011. A study of marketed and marketable surplus of rice in Bihar: A micro - level approach. Economic Affairs. 56(1).

Government of India (2015), Agricultural Statistics at a glance 2014, Directorate of Economics and Statistics, Department of Agricultura and Cooperation, Ministry of Agriculture and Oxford University Press, New Delhi.

Krishnan, T.N. 1965. The Marketed Surplus of Foodgrains: Is It Inversely Related to
Price. The Economic Weekly. 17 (5)

Kumar , Pramod. 1999. Marketed surplus of different crops across farm size: A study in Haryana. Indian Journal of Agricultural Economics. 54 (4):500521.

Sharma, Vijay Paul. 2016. Marketable and Marketed surplus of rice and wheat in India: Distribution and determinants. Indian Journal of Agriculture Economics.71 (2):137-159

Sharma, Vijay Paul and Harsh Wardhan. 2014. Assessment of Marketed and Marketable Surplus of Major Foodgrains in India, Report Submitted to the Ministry of Agriculture, Government of India, Centre for Management in Agriculture, Indian Institute of Management, Ahmedabad.

Singh, A. J., and Singh, A. 1992. An analysis of marketing pattern and factors affecting marketed surplus in Punjab A size wise analysis. Indian Journal of Agriculture Marketing. 6(1): 12-30.

Upender, M., 1992. Marketable and Marketed Surplus in Agriculture. Economic and Political Weekly. 27(28):1476-1479

\section{How to cite this article:}

Mohana Priya, K. S., R. Senthilkumar, C. Muralidharan and Pangayar Selvi, R. 2020. Analysis of Marketable and Marketed Surplus of Paddy in Tirunelveli District of Tamil Nadu, India. Int.J.Curr.Microbiol.App.Sci. 9(09): 1429-1433. doi: https://doi.org/10.20546/ijcmas.2020.909.181 